Bull. Chem. Soc. Ethiop. 2021, 35(2), 351-364.

(C) 2021 Chemical Society of Ethiopia and The Authors

ISSN 1011-3924

DOI: https://dx.doi.org/10.4314/bcse.v35i2.10

Printed in Ethiopia

Online ISSN 1726-801X

\title{
IN SITU ACETONITRILE/WATER MIXED SOLVENTS: AN ECOFRIENDLY SYNTHESIS AND STRUCTURE EXPLANATIONS OF Cu(II), Co(II), AND Ni(II) COMPLEXES OF THIOXOIMIDAZOLIDINE
}

\author{
Abeer M. Alosaimi ${ }^{1}$, Hosam A. Saad ${ }^{1 *}$, Ghaferah H. Al-Hazmi ${ }^{2}$ and Moamen S. Refat ${ }^{1}$ \\ ${ }^{1}$ Department of Chemistry, College of Science, Taif University, P.O. Box 11099, Taif 21944, \\ Saudi Arabia \\ ${ }^{2}$ Department of Chemistry, College of Science, Princess Nourah bint Abdulrahman \\ University, Riyadh 11671, KSA
}

(Received January 30, 2021; Revised May 3, 2021; Accepted May 3, 2021)

\begin{abstract}
The bidentate oxoacetate derivative of 4-oxo-2-thiazolidine 4ligand (L1) synthesized by the reaction of 1-(1-(Pyridin-3-yl)ethylideneamino)-2-thioxoimidazolidin-4-one 3 with diethyl oxalate with both traditional and microwave irradiation methods. The metal ion complexes of mixed ligands L1 and L2 (acetonitrile) were prepared by condensation a solution mixture of $\mathrm{Co}(\mathrm{II}) \mathrm{Ni}(\mathrm{II})$, and $\mathrm{Cu}(\mathrm{II})$ metal chloride salts with the ligands (L1 and L2) in distilled water with stirring. The complexes were characterized by the micro analysis $(\mathrm{C}, \mathrm{H}, \mathrm{N}$ ), chloride content, FT-IR, UV-Vis spectra, thermal gravimetric analysis (TGA), molar conductivity as well as magnetic susceptibility measurement. According to the obtained data the suggested coordination geometries of these complexes were suggested as octahedral structure. All the synthesized complexes were found to be electrolyte due to the presence of chloride ions outside the coordination sphere. The antibacterial activity of the L1 ligand and their metal ion complexes have been studied by screening against various microorganisms, $\mathrm{G}+$ bacteria (Bacillus subtillis, Streptococcus pneumonia, and Staphyloccoccus aurease), G-bacteria (E. coli, and Pesudomonas Sp.) and fungi (Aspergillus nigaer, and Penicillium Sp.). The metal ion complexes gave the formulae: $\left[\mathrm{M}(\mathrm{L} 1)(\mathrm{L} 2)_{2}\left(\mathrm{H}_{2} \mathrm{O}\right)_{2}\right] \mathrm{Cl}_{2}$ where $\mathrm{M}=\mathrm{Co}(\mathrm{II}) \mathrm{Ni}(\mathrm{II})$, and $\mathrm{Cu}(\mathrm{II})$.
\end{abstract}

KEY WORDS: Imidazolidine, Microwave irradiation, Transition metals complexes, Biological activity

\section{INTRODUCTION}

Among the several of objectives in organic and medicinal chemistry, one of these objectives is the design and synthesis compounds having valuable therapeutic agents for human. Sulfur analog of hydantoins [2-thioxo-imidazolin-4-one] belongs to the class of heterocycles which proven good utility in medicinal chemistry [1]. Thiohydantoins, 2-thioxo-imidazolidine-4one [2], are amazing compounds due to their wide applications. Beside their novel uses in treatment of prostate cancer treatment [3-5], castration-resistant prostate cancer (mCRPC) [6] and metastatic castration-resistant prostate cancer (CRPC) [7], they also, applied as inhibitors for $\alpha$ glucosidase and $\alpha$-amylase enzymes activities for treatment of diseases related to diabetes [8]. Thiohydantoins also showed good effects as antimutagenic [9], antiviral (e.g., against herpes simplex virus, HSV) [10], human immunodeficiency virus (HIV) [11], tuberculosis [12], anticarcinogenic [13], anti-ulcer and anti-inflammatory agents [14], hypolipidemic [15], antithyroidal [16], and antimicrobial (antifungal and antibacterial) [17]. Additionally, thiohydantoins have been used in C terminal protein sequencing development [18]. The field of research, including the synthesis of mixed bonding complexes, has gained much interest in recent years. The growing interest in this field of research has prompted many researchers to work in this field and as a result, a huge amount of literature has been published in this field [922]. Mixed ligand complexes are different from classical complexes in the sense that they contain more than one type of bond attached to the same metal atom in the complex. This sharing of more than one type of bond in a metal complex creates an opportunity to alter the

*Corresponding author. E-mail: h.saad@tu.edu.sa

This work is licensed under the Creative Commons Attribution 4.0 International License 
expected properties of the collector due to structural differences. This could lead to a variety of applications and thus maintain the interest of researchers [19-22]. Herein in this article, we present the synthesis and characterization of three new mixed ligand metal (copper(II), cobalt(II), and nickel(II)) complexes with $\mathrm{N}$, and $\mathrm{O}$ donor ligands complexes derivatives of ethyl 2-oxo-2-(4-oxo-3-(1-(pyridin-3-yl)ethylideneamino)-2-thioxoimid azolidin-1-yl)acetate 4 (L1). Moreover, the preliminary in vitro $\mathrm{G}+$ bacteria (Bacillus subtillis, Streptococcus pneumonia, and Staphyloccoccus aurease), G-bacteria (E. coli, and Pesudomonas Sp.) and fungi (Aspergillus nigaer, and Penicillium Sp.) screening activities of the complexes obtained are carried out and the results are reported herein.

\section{EXPERIMENTAL}

General

All melting points were taken on an Electrothermal IA 9100 series digital melting point apparatus. The IR spectra $(\mathrm{KBr})$ discs were recorded on a Perkin-Elmer 1650 spectrometer. ${ }^{1} \mathrm{H}-$ and ${ }^{13} \mathrm{C}$-NMR spectra were recorded on a Bruker AC-400 Hz instrument. Chemical shifts were expressed as $\delta(\mathrm{ppm})$ relative to TMS as internal standard and DMSO- $\mathrm{d}_{6}$ as solvent. The elemental analysis was performed at the Micro-Analytical Center, Cairo University on a Perkin Elmer 2400 CHN analyzer. Mass spectra were recorded on a Shimadzu GC-MS-QP 1000 EX spectrometer. A domestic microwave oven was used $(2450 \mathrm{MHz}, 800 \mathrm{~W})$. The electronic spectra were recorded in the range $200-800 \mathrm{~nm}$ at room temperature in the solid state using a UV2 Unicam UV/Vis Spectrophotometer. The magnetic moments were determined on a Guoy balance and the diamagnetic corrections of the complexes were calculated using Pascal's constants. Molar conductivities were measured in DMSO solution at $10^{-3} \mathrm{M}$ concentration using a Jenway 4010 conductivity meter. The metal contents were estimated with a gravimetrically method. Thermogravimetric analysis of the complexes was performed from room temperature to $800{ }^{\circ} \mathrm{C}$ using a TGA/DTA-50H Shimadzu thermal analyzer.

Antimicrobial activity of the tested samples was determined using a modified Kirby-Bauer disc diffusion method [23]. Briefly, $100 \mu \mathrm{L}$ of the best bacteria/fungi were grown in $10 \mathrm{~mL}$ of fresh media until they reached a count of approximately 108 cells $/ \mathrm{mL}$ for bacteria or 105 cells $/ \mathrm{mL}$ for fungi [24]. $100 \mu \mathrm{L}$ of microbial suspension was spread onto agar plates corresponding to the broth in which they were maintained. Isolated colonies of each organism that might be playing a pathogenic role should be selected from primary agar plates and tested for susceptibility by disc diffusion method $[25,26]$.

Synthesis of 3-((1-Aminocarbonothioyl)hydrazono)ethylpyridine (2)

Method A. To a solution of 2-Acetylpyridine $(1.21 \mathrm{~g}, 0.01 \mathrm{~mol})$ in glacial acetic acid $(20 \mathrm{~mL})$, thiosemicarbazide $(0.9 \mathrm{~g}, 0.01 \mathrm{~mol})$ added and the resulting mixture stirred with reflux for $3 \mathrm{~h}$ (the progress of reaction was monitored by TLC), then cooled. The product formed filtered off and crystallized from $\mathrm{MeOH}$ to give yellowish crystals (yield 60\%), m.p. $243-245^{\circ} \mathrm{C}$.

Method B. In a dry glass beaker, 2-acetylpyridine $(1.21 \mathrm{~g}, 0.01 \mathrm{~mol})$ and thiosemicarbazide $(0.9$ gm, $0.01 \mathrm{~mol})$, mixed and dissolved in $\mathrm{CH}_{2} \mathrm{Cl}_{2}(20 \mathrm{~mL})$, then $1 \mathrm{~g}$ of silica gel (200-400 mesh) added, the solvent evaporated on cold, the dried mixture irradiated for 1.5-2.0 min in a domestic microwave oven $(2450 \mathrm{MHz}, 800 \mathrm{~W})$. The product formed isolated from silica gel by adding acetone and filtered off. After acetone evaporation, the product formed crystallized from $\mathrm{MeOH}$ to give pale yellow crystals. Yield $91 \%$, m.p. $244-246^{\circ} \mathrm{C}$. 
Synthesis of 1-(1-(pyridin-3-yl)ethylideneamino)-2-thioxoimidazolidin-4-one (3)

Method A. Compound 1 (1.94 g, $0.01 \mathrm{~mol})$ mixed with ethyl chloroacetate $(1.22 \mathrm{~g}, 0.01 \mathrm{~mol})$ and refluxed with stirring in DMF $(20 \mathrm{~mL}$ ) for $4 \mathrm{~h}$ (the progress of reaction was monitored by TLC), the reaction mixture cooled, then, poured onto ice-water and the precipitate formed crystallized from $\mathrm{MeOH}$ to give orange crystals (yield $75 \%$ ), m.p. $261-263{ }^{\circ} \mathrm{C}$.

Method $B$. In a dry glass beaker, compound 1 (1.94 g, $0.01 \mathrm{~mol})$ mixed with ethyl chloroacetate $(1.22 \mathrm{~g}, 0.01 \mathrm{~mol})$, and the mixture dissolved in $\mathrm{CH}_{2} \mathrm{Cl}_{2}(20 \mathrm{~mL})$ then $1.0 \mathrm{~g}$ of silica gel added (200-400 mesh). The solvent evaporated on cold, the dried mixture irradiated for 3.0-3.5 min in a domestic microwave oven $(2450 \mathrm{MHz}, 800 \mathrm{~W})$. The formed product separated from silica gel by dissolving in acetone and filtered off. The acetone evaporated and the product formed crystallized from $\mathrm{MeOH}$ to give orange crystals. Yield $90 \%$, m.p. $262-264{ }^{\circ} \mathrm{C}$.

Synthesis of ethyl 2-oxo-2-(4-oxo-3-(1-(pyridin-3-yl)ethylideneamino)-2-thioxoimidazolidin-1yl)acetate 4 .

Method A. A mixture of 3 (2.34 g, $0.01 \mathrm{~mol})$ and diethyl oxalate $(1.46 \mathrm{~g}, 0.01 \mathrm{~mol})$ in DMF (15 $\mathrm{mL}$ ) stirred under reflux for $5 \mathrm{~h}$, (the progress of reaction was monitored by TLC), the reaction mixture poured onto ice-water after cooling and the crude material formed filtered off and crystallized from $\mathrm{MeOH}$ to give yellow crystals (yield 78\%), m.p. $210-212{ }^{\circ} \mathrm{C}$.

Method B. In a dry glass beaker, a mixture of $3(2.34 \mathrm{~g}, 0.01 \mathrm{~mol})$ and diethyl oxalate $(1.46 \mathrm{~g}$, $0.01 \mathrm{~mol})$, dissolved in $\mathrm{CH}_{2} \mathrm{Cl}_{2}(20 \mathrm{~mL})$ then silica gel added $(1.0 \mathrm{~g}, 200-400 \mathrm{mesh})$, the solvent evaporated on cold, the dried mixture irradiated for 2.0-3.0 min in a domestic microwave oven $(2450 \mathrm{MHz}, 800 \mathrm{~W})$. The product extracted from silica gel by with acetone. The product formed after acetone evaporation crystallized from methanol to give yellow crystals. Yield $90 \%$, m.p. $214-216^{\circ} \mathrm{C}$

\section{Synthesis of $\mathrm{Cu}(I I), \mathrm{Co}(I I)$, and $\mathrm{Ni}(\mathrm{II})$ complexes}

The present mixed complexes were prepared by mixing equal amounts $(1 \mathrm{mmol})$ of hot saturated, acetonitrile solution of the ligand ethyl 2-oxo-2-(4-oxo-3-(1-(pyridin-3yl)ethylideneamino)-2-thioxoimid azolidin-1-yl)acetate 4 (L1) with the same ratio of Co(II) $\mathrm{Ni}(\mathrm{II})$, and $\mathrm{Cu}(\mathrm{II})$ metal chlorides salts. The mixture was refluxed for $3 \mathrm{~h}$ at $60{ }^{\circ} \mathrm{C}$. The resulting complexes were filtered and washed several times with methanol until the filtrates become clear. The solid complexes then dried in desiccator over anhydrous calcium chloride.

\section{RESULTS AND DISCUSSION}

\section{3-1-Interpretation of thioxoimidazolidine derivative (4) ligand}

Synthesis of ethyl 2-oxo-2-(4-oxo-3-(1-(pyridin-3-yl)ethylideneamino)-2-thioxoimidazolidin-1yl)acetate was our target in this work for studying both its biological activity against number of micro-organisms and its metal ion complexes formed when reacted with different metal salts. The formation of the target compound started by synthesis of the starting material 3-((1aminocarbonothioyl)hydrazono)ethylpyridine $\mathbf{2}$ from 3-acetylpyridine reacted with thiosemicarbazide in glacial acetic acid. The yield of compound 2 was $60 \%$, this yield encouraged us to follow the microwave technique for improving yield and purity of the product. Therefore, compound 2 synthesized under microwave irradiation with a domestic microwave oven over silica gel (200-400 mesh) (2450 MHz, $800 \mathrm{~W})$ (Scheme 1), the products formed in 
microwave irradiation was $91 \%$ which is one and half the amount resulted by traditional method.<smiles>CC(=O)c1cccnc1</smiles><smiles>CCOC(=O)C(=O)OCC</smiles>

Scheme 1. Synthesis of 2-thiothioxoimidazolidinone derivative.

3-((1-Aminocarbonothioyl)hydrazono)ethylpyridine (2)

IR: $3289-3186 \mathrm{~cm}^{-1}\left(\mathrm{NH}_{2}\right.$ and $\left.\mathrm{NH}\right), 2665 \mathrm{~cm}^{-1}$ (C=S thiamide). ${ }^{1} \mathrm{H}$ NMR (DMSO- $d_{6}, 300 \mathrm{Mz}$ ): $\delta=2.623\left(\mathrm{~s}, 3 \mathrm{H}, \mathrm{CH}_{3}\right), 7.07\left(\mathrm{dd}, 1 \mathrm{H}\right.$, pyridine $\left.C_{5} \mathrm{H}\right), 7.50\left(\mathrm{~d}, 1 \mathrm{H}, J=9.00\right.$, pyridine $\left.C_{4} \mathrm{H}\right), 7.58$ $\left(\mathrm{s}, 2 \mathrm{H}, \mathrm{NH}_{2}\right), 7.67\left(\mathrm{~d}, 1 \mathrm{H}, J=6.00\right.$, pyridine $\left.C_{6} \mathrm{H}\right), 7.93\left(\mathrm{~s}, 1 \mathrm{H}\right.$, pyridine $\left.C_{2} \mathrm{H}\right), 10.17(\mathrm{~s}, 1 \mathrm{H}$, $\mathrm{NH}) .{ }^{13} \mathrm{C}-\mathrm{NMR}$ (DMSO- $\left.d_{6}, 75 \mathrm{Mz}\right): \delta=13.06\left(\mathrm{CH}_{3}\right), 121.4$ (pyridine $C_{5}$ ), 134.8 (pyridine $C_{3}$ ), 138.5 (pyridine $\left.C_{4}\right), 145.7(\mathrm{C}=\mathrm{N}), 149.8$ (pyridine $\left.C_{6}\right), 153.3$ (pyridine $\left.C_{2}\right), 173.7(\mathrm{C}=\mathrm{S})$. Anal. calcd for $\mathrm{C}_{8} \mathrm{H}_{10} \mathrm{~N}_{4} \mathrm{~S}$ (194.26): C, 49.46; H, 5.19; N, 28.84; S, 16.51; found: C, 49.12; H, 5.61; N, 28.74; S, 16.32. MS m/z (int. \%): 194 (100), 169 (49.4), 168 (64.6), 141 (17.7), 140 (71.0), 129 (20.0), 115 (31.7), 114 (28.6), 113 (64.0), 112 (20.29), 100 (15.9), 99 (21.76), 88 (50.6), 87 (64.6), 86 (34.5), 85 (25.3), 76 (38.0), 75 (39.4), 71 (34.5), 64 (45.8), 63 (61.8), 62 (71.1).

1-(1-(Pyridin-3-yl)ethylideneamino)-2-thioxoimidazolidin-4-one (3)

IR: $3177 \mathrm{~cm}^{-1}(\mathrm{NH}), 2640 \mathrm{~cm}^{-1}\left(\mathrm{C}=\mathrm{S}\right.$ thiamide), $1645 \mathrm{~cm}^{-1}$ ( $\mathrm{C}=\mathrm{O}$ amide). ${ }^{1} \mathrm{H}$ NMR (DMSO- $d_{6}$, $300 \mathrm{Mz}): \delta=2.37\left(\mathrm{~s}, 3 \mathrm{H}, \mathrm{CH}_{3}\right), 4.40\left(\mathrm{~s}, 2 \mathrm{H}\right.$, imidazolidine $\left.\mathrm{CH}_{2}\right), 7.09\left(\mathrm{dd}, 1 \mathrm{H}\right.$, pyridine $\left.C_{5} \mathrm{H}\right)$, $7.51\left(\mathrm{~d}, 1 \mathrm{H}, J=9.00\right.$, pyridine $\left.C_{4} \mathrm{H}\right), 7.60\left(\mathrm{~d}, 1 \mathrm{H}, J=6.00\right.$, pyridine $\left.C_{6} \mathrm{H}\right), 7.95(\mathrm{~s}, 1 \mathrm{H}$, pyridine $\left.C_{2} \mathrm{H}\right), 10.28(\mathrm{~s}, 1 \mathrm{H}, \mathrm{NH}) .{ }^{13} \mathrm{C}-\mathrm{NMR}\left(\mathrm{DMSO}-d_{6}, 75 \mathrm{Mz}\right): \delta=15.15\left(\mathrm{CH}_{3}\right), 63.96\left(\mathrm{CH}_{2}\right), 121.8$ (pyridine $C_{5}$ ), 134.9 (pyridine $\left.C_{3}\right), 135.5$ (pyridine $\left.C_{4}\right), 138.7(\mathrm{C}=\mathrm{N}), 142.9$ (pyridine $\left.C_{6}\right), 153.3$ (pyridine $\left.C_{2}\right), 164.3(\mathrm{C}=\mathrm{O}), 170.7(\mathrm{C}=\mathrm{S})$. Anal. calcd for $\mathrm{C}_{10} \mathrm{H}_{10} \mathrm{~N}_{4} \mathrm{OS}(234.28)$ : $\mathrm{C}, 51.27 ; \mathrm{H}$, 4.30; N, 23.91; S, 13.69; found: C, 51.03; H, 4.11; N, 23.81; S, 13.60. MS $m / z$ (int. \%): 234 (45.5), 206 (31.2), 185 (73.3), 175 (47.1), 157 (11.51), 146 (3.80), 129 (9.14), 118 (8.53), 103 (32.93), 90 (14.83), 76 (67.56), 64 (100), 55 (59.05).

Ethyl 2-oxo-2-(4-oxo-3-(1-(pyridin-3-yl)ethylideneamino)-2-thioxoimid azolidin-1-yl)acetate (4)

IR: $2665 \mathrm{~cm}^{-1}(\mathrm{C}=\mathrm{S}), 1725,1636$ and $1602 \mathrm{~cm}^{-1}(3 \mathrm{C}=\mathrm{O}) 835 \mathrm{~cm}^{-1}(\mathrm{C}=\mathrm{S}$ thiamide $), 1624 \mathrm{~cm}^{-1}$ $\left(\mathrm{C}=\mathrm{O}\right.$ amide) ${ }^{1} \mathrm{H}$ NMR (DMSO- $\left.d_{6}, 300 \mathrm{Mz}\right): \delta=1.03\left(\mathrm{~s}, 3 \mathrm{H}, \mathrm{C}_{3}\right), 1.50\left(\mathrm{t}, 3 \mathrm{H}, \mathrm{CH}_{2} \mathrm{C}_{3}\right), 4.07$ (q, $\left.2 \mathrm{H}, \mathrm{CH}_{2} \mathrm{CH}_{3}\right), 4-18-4.23\left(2 \mathrm{~d}, 2 \mathrm{H}\right.$, imidazolidine $\left.\mathrm{CH}_{2}\right), 7.22\left(\mathrm{dd}, 1 \mathrm{H}\right.$, pyridine $\left.C_{5} \mathrm{H}\right), 7.25(\mathrm{~d}$, $1 \mathrm{H}, J=8.60$, pyridine $\left.C_{4} \mathrm{H}\right), 7.92\left(\mathrm{~d}, 1 \mathrm{H}, J=6.40\right.$, pyridine $\left.C_{6} \mathrm{H}\right), 7.89\left(\mathrm{~s}, 1 \mathrm{H}\right.$, pyridine $\left.C_{2} \mathrm{H}\right)$.

${ }^{13} \mathrm{C}-\mathrm{NMR}$ (DMSO- $\left.d_{6}, 75 \mathrm{Mz}\right): \delta=13.15\left(\mathrm{~N}=\mathrm{C}-\underline{\mathrm{C}} \mathrm{H}_{3}\right), 13.94\left(\mathrm{CH}_{2} \underline{C}_{3}\right), 63.96$ (imidazolidine 
$\mathrm{CH}_{2}$ ), $67.32\left(\mathrm{CH}_{2} \mathrm{CH}_{3}\right), 122.3$ (pyridine $C_{5}$ ), 134.4 (pyridine $C_{3}$ ), 135.8 (pyridine $C_{4}$ ), 150.7 $(\mathrm{C}=\mathrm{N}), 152.9\left(\right.$ pyridine $\left.C_{6}\right), 155.5$ (pyridine $\left.C_{2}\right), 156.9$ (imidazolidine $\left.\mathrm{C}=\mathrm{O}\right), 161.4(\mathrm{C}=\mathrm{O} \underline{C}=\mathrm{O})$, $163.3(\underline{C}=\mathrm{OC}=\mathrm{O}), 170.7$ (imidazolidine $\mathrm{C}=\mathrm{S})$. Anal. calcd for $\mathrm{C}_{14} \mathrm{H}_{14} \mathrm{~N}_{4} \mathrm{O}_{4} \mathrm{~S}(334.35)$ : $\mathrm{C}, 50.29$; H, 4.22; N, 16.76; S, 9.59; found: C, 50.11; H, 4.09; N, 16.58; S, 9.51. MS $m / z$ (int. \%): $\left(\mathrm{M}^{+}+1\right)$ 335 (2.6), $\mathrm{M}^{+} 334$ (11.7), 333 (13.7), 319 (30.3), 274 (10.3), 234 (3.2), 215 (0.5), 170 (1.0), 119 (44.5), 118 (44.8), 113 (4.8), 104 (38.8), 101 (7.1), 78 (96.9), 76 (25.9), 69 (32.2), 53 (6.7), 51 (100.0), 50 (97.3).

${ }^{1} \mathrm{H},{ }^{13} \mathrm{C}$ NMR, IR spectra and micro analytical data confirmed the structure of the 3-((1aminocarbonothioyl)hydrazono)ethylpyridine 2. The carbonyl group in the starting material acetylpyridine disappeared with appearance each of $\mathrm{C}=\mathrm{S}, \mathrm{NH}$ and $\mathrm{NH}_{2}$ bands at the range 3289$3186 \mathrm{~cm}^{-1}$ due to $\mathrm{NH}_{2}$ and $\mathrm{NH}$, also, showed band at $2665 \mathrm{C}=\mathrm{S}$ stretching and $830 \mathrm{~cm}^{-1}$ due to $\mathrm{C}=\mathrm{S}$ bending. The ${ }^{1} \mathrm{H}$ NMR showed a singlet due to $\mathrm{NH}_{2}$ group at $\delta=7.58 \mathrm{ppm}$ and another singlet due to $\mathrm{NH}$ at $\delta=10.17 \mathrm{ppm}$. The ${ }^{1} \mathrm{H}$ NMR chart for compound 2 shown in Figure 1. $\mathrm{C}=\mathrm{S}$ group showed peak at 173.7 in its ${ }^{13} \mathrm{C}$ NMR as shown in Figure 2. Compound $\mathbf{3}$ synthesized with the same two mentioned methods, traditional and microwave irradiation, as illustrated in Scheme 1. The reaction of compound 2 with ethyl chloroacetate under reflux in DMF as a solvent yielded 1-(1-(pyridin-3-yl)ethylideneamino)-2-thioxoimidazolidin-4-one 3. The reaction repeated under microwave irradiation, the products product in case of microwave irradiation shows a more yield amount and melting point increases by one degree. The ${ }^{1} \mathrm{H}$ NMR spectrum of compound 3 showed singlet at $\delta=4.40 \mathrm{ppm}$ referring to the presence of two protons due to imidazolidine $\mathrm{CH}_{2}$ protons, Figure 3. Also, while, its ${ }^{13} \mathrm{C}$ NMR showed peaks at $\delta=63.96$, 164.3 and $170.7 \mathrm{ppm}$ due to the imidazolidine $\mathrm{CH}_{2}, \mathrm{C}=\mathrm{O}$ and $\mathrm{C}=\mathrm{S}$, respectively, Figure 4 .

Compound 4 prepared by the reaction of compound 3 with diethyl oxalate in DMF under reflux conditions, also, the reaction between compound 3 and diethyl oxalate carried out under microwave irradiation. The structure of compound 4, ethyl 2-oxo-2-(4-oxo-3-(1-(pyridin-3yl)ethylideneamino)-2-thioxoimidazolidin-1-yl)acetate, elucidatedfrom its ${ }^{1} \mathrm{H},{ }^{13} \mathrm{C}$ NMR, IR, and mass spectra. Compound 4 (Figure 5) showed in its ${ }^{1} \mathrm{H}$ NMR two doublets due to two protons of different electronic environments at $\delta=4-18-4.23 \mathrm{ppm}$ due to the $\mathrm{CH}_{2}$ group of thiazolidine ring. The splitting of the two protons resulted from the presence of the oxo acetate group near the $\mathrm{CH}_{2}$ group protons. Also, the ${ }^{1} \mathrm{H}$ NMR of compound 4 showed triplet and quartet due to the ethyl group at $\delta=1.50$ and $4.07 \mathrm{ppm}$, respectively. The ${ }^{13} \mathrm{C}$ NMR of compound 4 (Figure 6), showed two signals due to the oxoacetate $\mathrm{C}=\mathrm{O}$ groups at $\delta=161.4$ and $163.3 \mathrm{ppm}$. The fragmentation pattern and mass spectrum chart for compound 4 are shown in Figure 7 and Figure 8, respectively. 


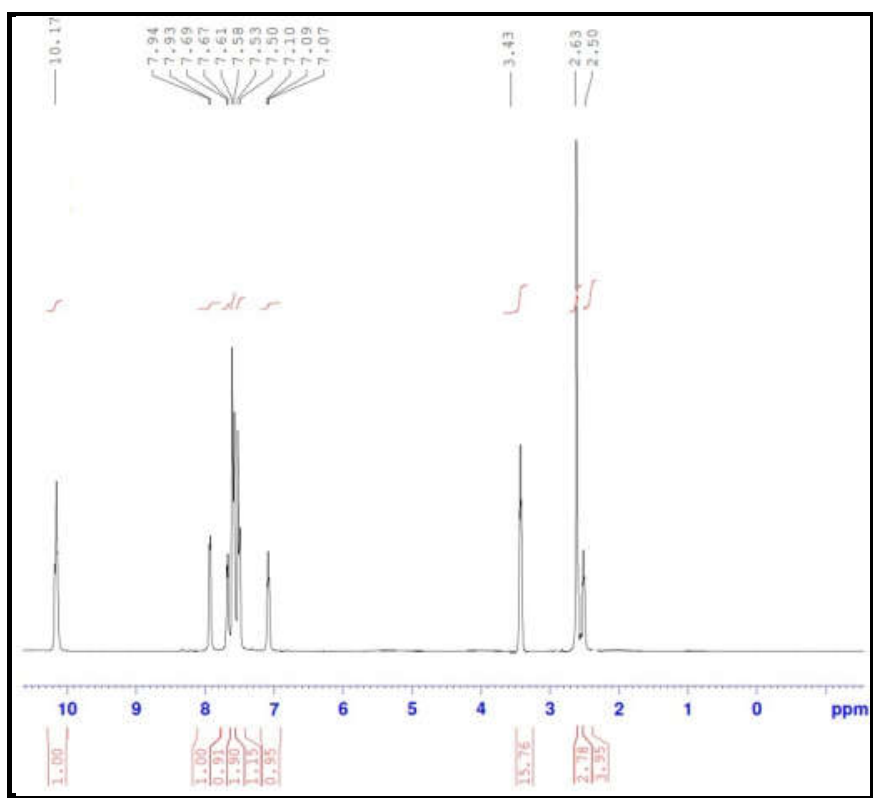

Figure 1. ${ }^{1} \mathrm{H}$ NMR of compound 2.

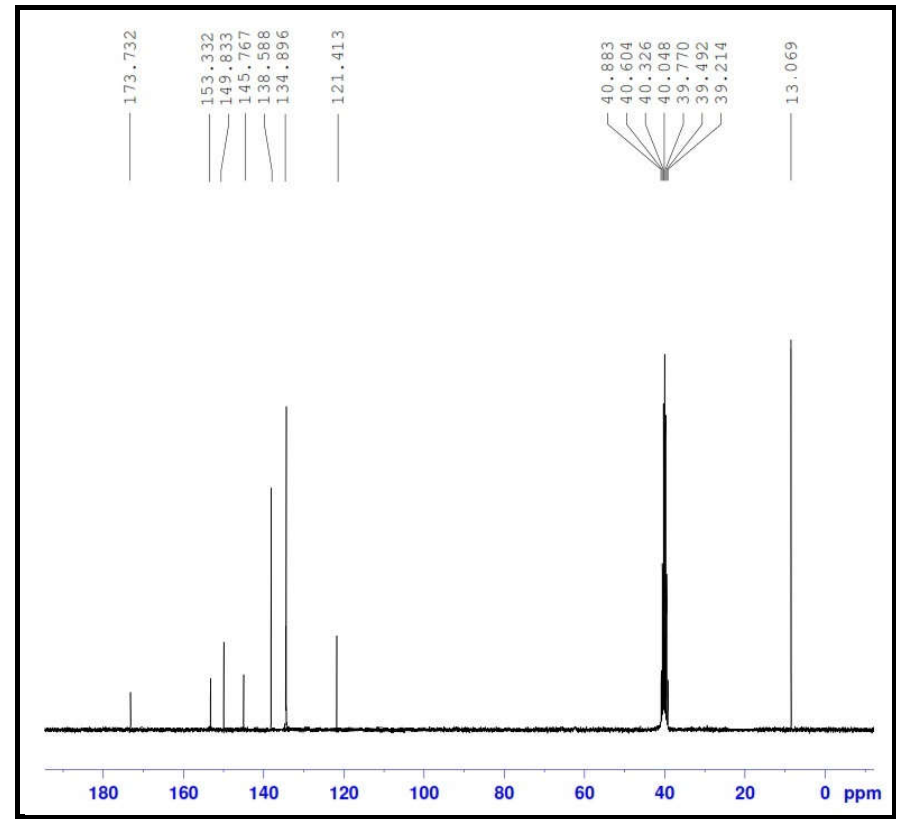

Figure 2. ${ }^{13} \mathrm{C}$ NMR of compound 2 .

Bull. Chem. Soc. Ethiop. 2021, 35(2) 
An ecofriendly synthesis and structure explanations of $\mathrm{Cu}(\mathrm{II}), \mathrm{Co}(\mathrm{II})$, and $\mathrm{Ni}$ (II) complexes 357

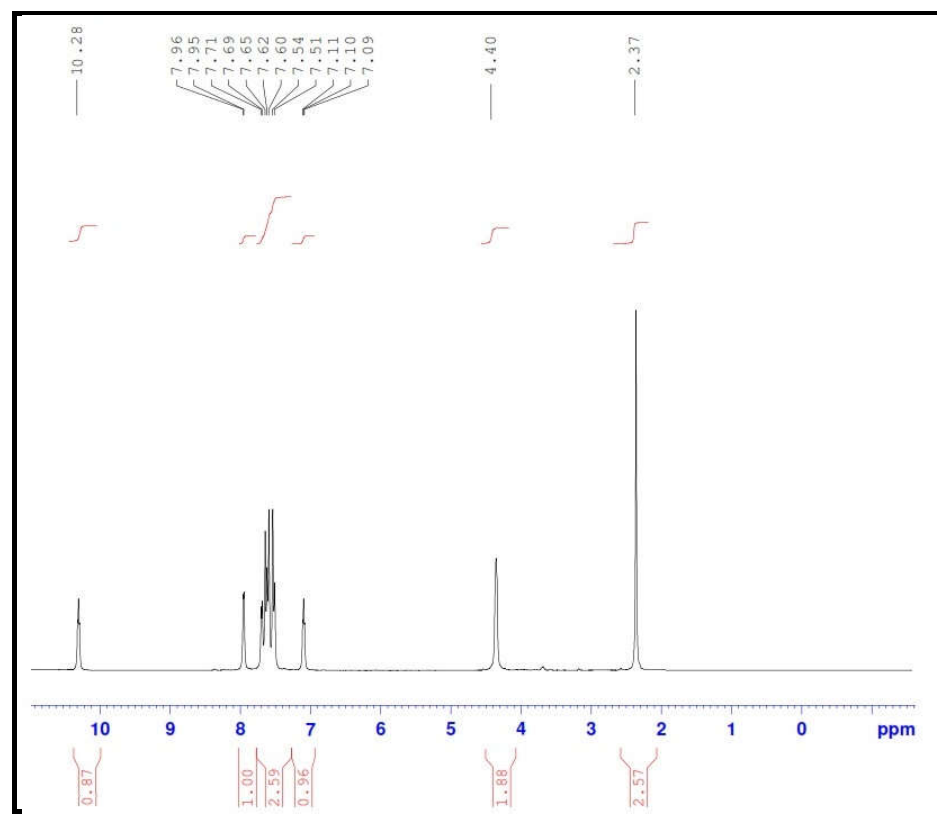

Figure $3 .{ }^{1} \mathrm{H}$ NMR of compound 3 .

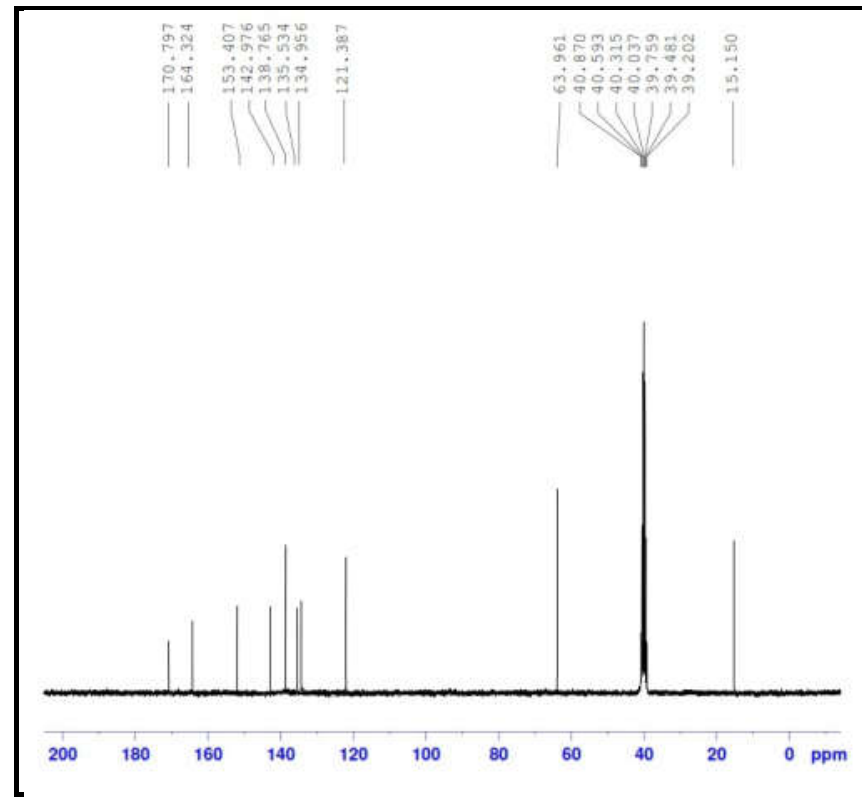

Figure $4 .{ }^{13} \mathrm{C}$ NMR of compound 3 .

Bull. Chem. Soc. Ethiop. 2021, 35(2) 


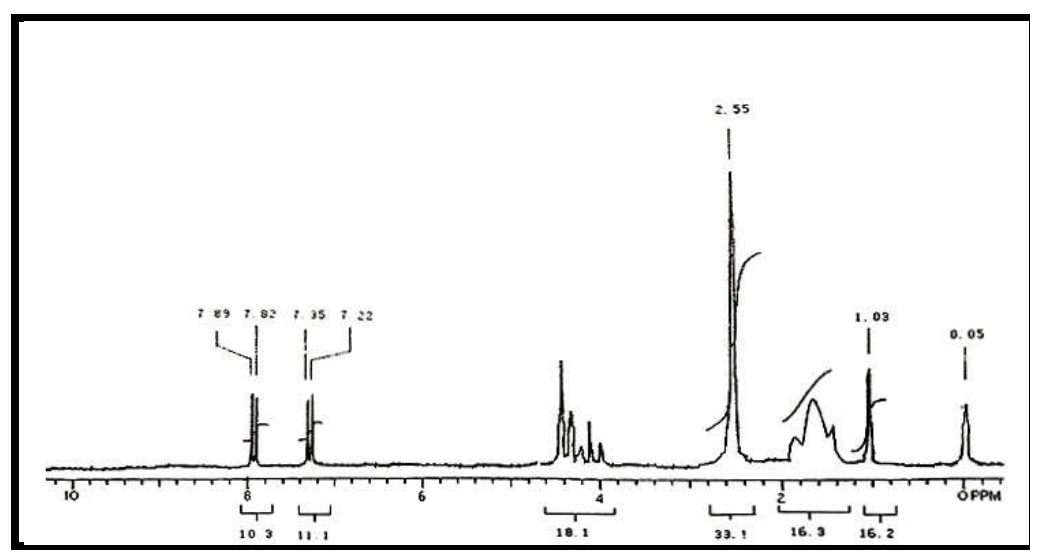

Figure 5. ${ }^{1} \mathrm{H}$ NMR of compound 4.

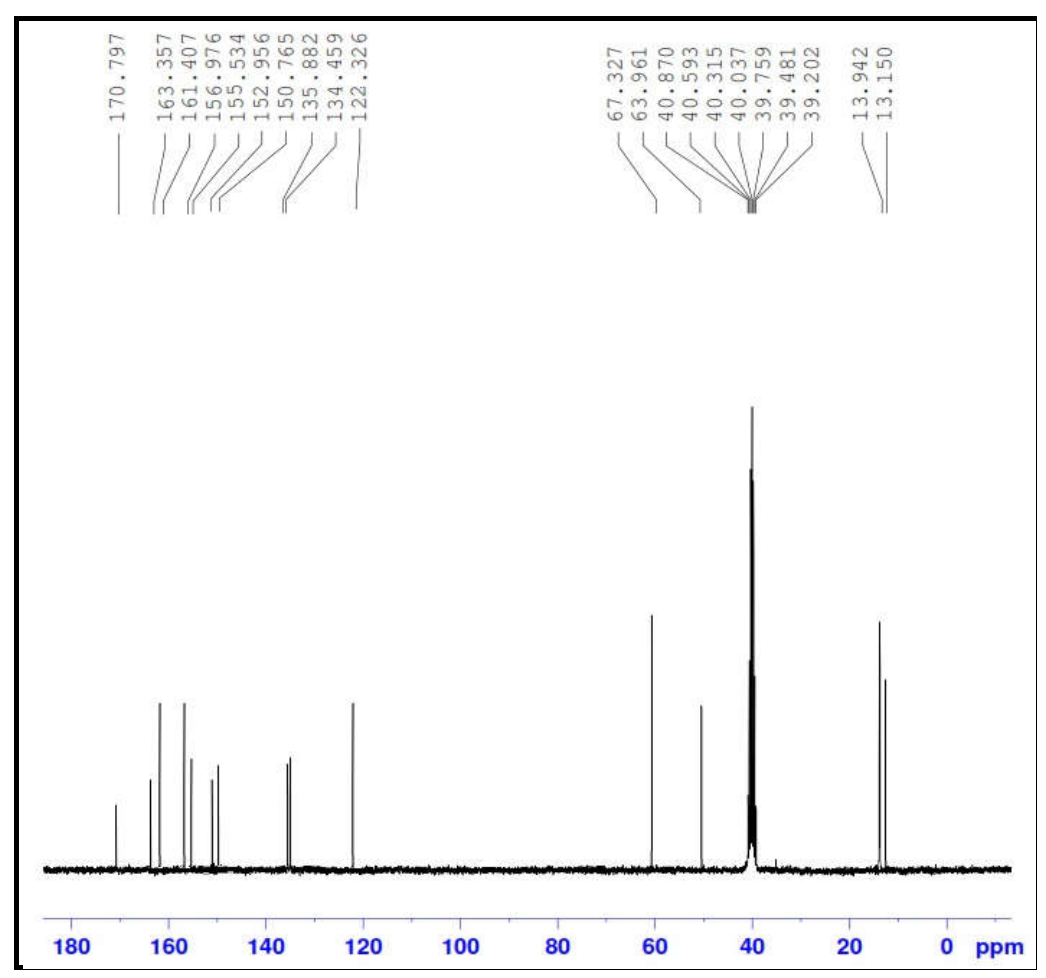

Figure 6. ${ }^{13} \mathrm{C}$ NMR of compound 4.

Bull. Chem. Soc. Ethiop. 2021, 35(2) 
An ecofriendly synthesis and structure explanations of $\mathrm{Cu}(\mathrm{II}), \mathrm{Co}(\mathrm{II})$, and $\mathrm{Ni}(\mathrm{II})$ complexes 359

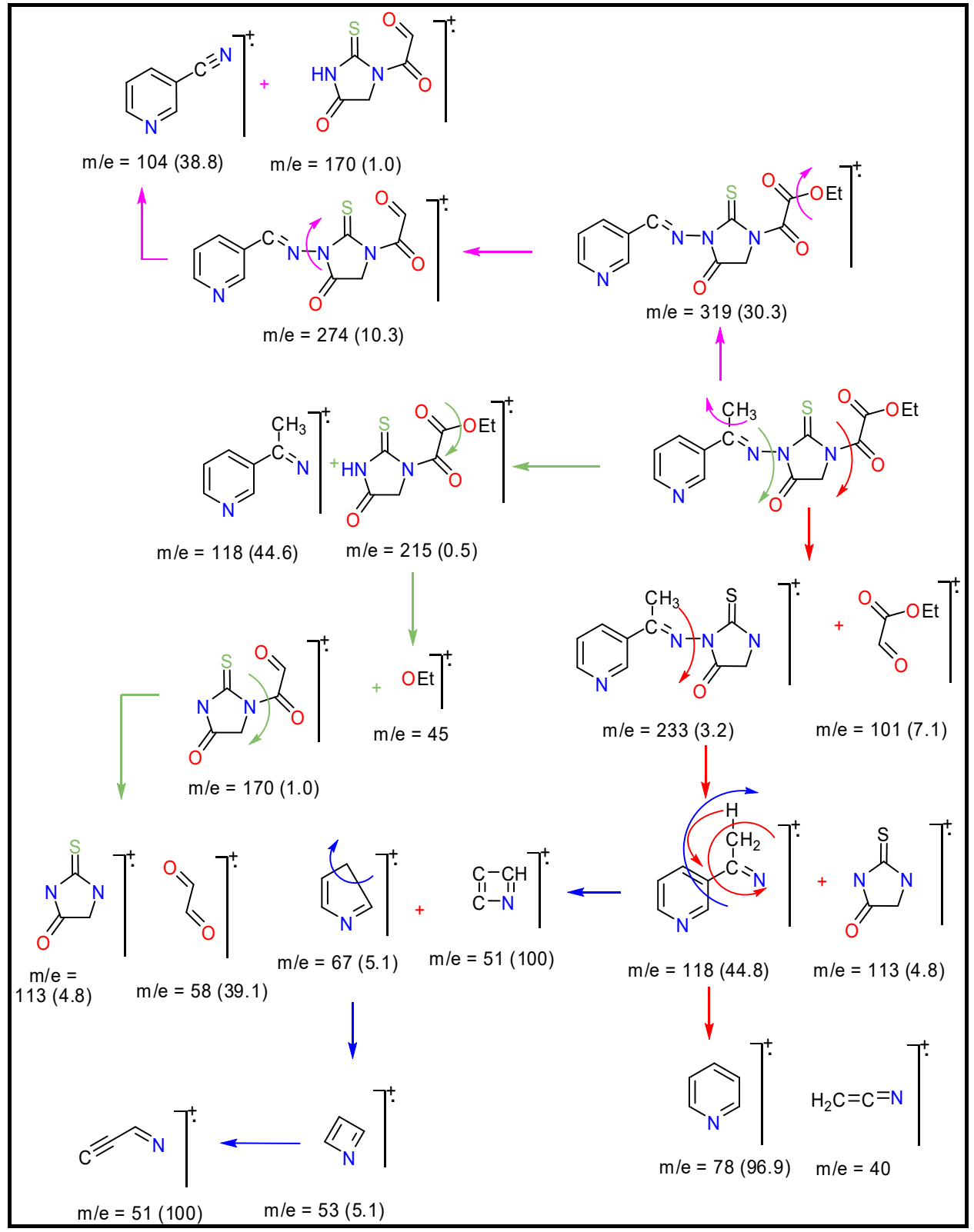

Figure 7. Mass fragmentation of compound 4.

Bull. Chem. Soc. Ethiop. 2021, 35(2) 

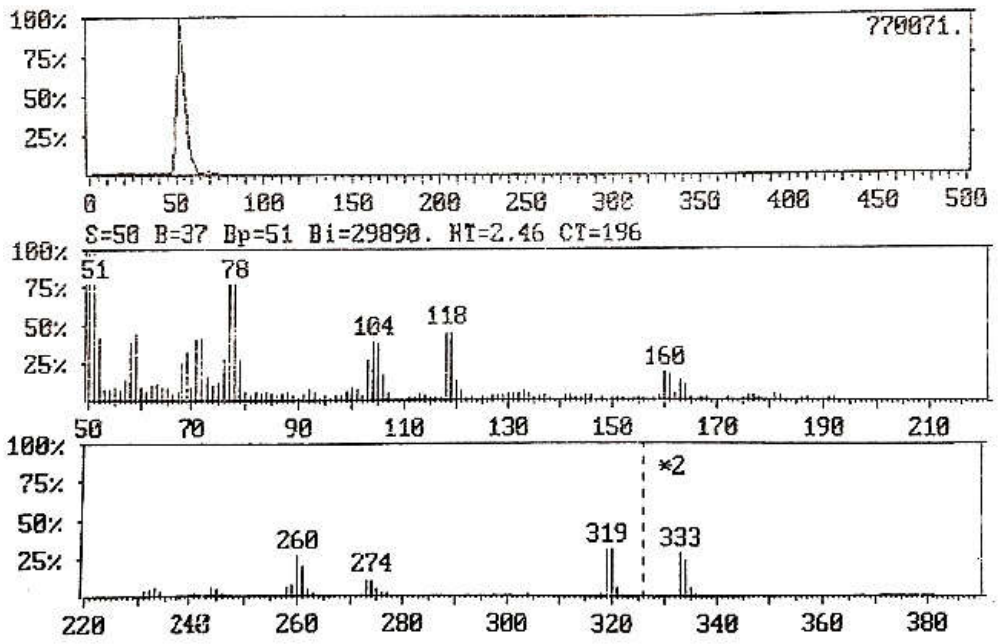

Figure 8. Mass spectrum of compound 4.

Interpretation of $\mathrm{Cu}(\mathrm{II}), \mathrm{Co}(\mathrm{II})$, and $\mathrm{Ni}(\mathrm{II})$ complexes

Microanalytical and molar conductance studies

The structures, of the prepared metal ion complexes were identified, by elemental analysis, FTIR and UV-Visible with some other techniques. The molar conductance values of the synthetic complexes obtained in dimethyl sulfoxide (DMSO) as a solvent at room temperature were listed in Table 1. These results were showed that $\mathrm{Cu}(\mathrm{II}), \mathrm{Co}(\mathrm{II})$, and $\mathrm{Ni}(\mathrm{II})$ complexes have a molar conductivity value of 126,139 and $114 \mathrm{ohm}^{-1} \mathrm{~cm}^{2} \mathrm{~mol}^{-1}$, respectively, which were indicated the ionic nature [27]. It is obvious from these data that, these complexes are ionic in nature and they are of the type 1:1 electrolyte [28]. Microanalytical: Anal. calcd for copper(II) complex: C, 36.84; H, 4.12; N, 14.32; Cl, 12.08; Cu, 10.83. Found: C, 36.80; H, 4.11; N, 14.27; Cl, 12.02; $\mathrm{Cu}, 10.76$. Anal. calcd for cobalt(II) complex C, 37.13; H, 4.15; N, 14.43; Cl, 12.18; Co, 10.10.12. Found: C, 37.12; H, 4.11; N, 14.41; Cl, 12.11; Co, 10.01. Anal. calcd for nickel(II) complex: C, 37.14; H, 4.16; N, 14.44; Cl, 12.18; Ni, 10.08. Found: C, 37.06; H, 4.11; N, 14.36; $\mathrm{Cl}, 12.11 ; \mathrm{Ni}, 10.02$.

Table 1. Analytical data of $\mathrm{Cu}(\mathrm{II}), \mathrm{Co}(\mathrm{II})$, and $\mathrm{Ni}(\mathrm{II})$ complexes.

\begin{tabular}{|l|l|c|c|c|c|}
\hline Compounds & Molecular formula (Mwt) & Color & M.p/ $/{ }^{\circ} \mathrm{C}$ & $\mu_{\text {eff }} /$ B.M & $\Lambda_{\mathrm{m}} / \mathrm{ohm}^{-1} \mathrm{~cm}^{2} \mathrm{~mol}^{-1}$ \\
\hline $\mathrm{Cu}(\mathrm{II})$ complex & $\mathrm{C}_{18} \mathrm{H}_{24} \mathrm{Cl}_{2} \mathrm{~N}_{6} \mathrm{O}_{6} \mathrm{SCu}(585.02)$ & Green & $>350$ & 1.81 & 126 \\
\hline $\mathrm{Co}(\mathrm{II})$ complex & $\mathrm{C}_{18} \mathrm{H}_{24} \mathrm{Cl}_{2} \mathrm{~N}_{6} \mathrm{O}_{6} \mathrm{SCo}(582.32)$ & Red & $>350$ & 4.42 & 139 \\
\hline $\mathrm{Ni}$ (II) complex & $\mathrm{C}_{18} \mathrm{H}_{24} \mathrm{Cl}_{2} \mathrm{~N}_{6} \mathrm{O}_{6} \mathrm{SNi}(580.02)$ & Green & $>350$ & 3.28 & 114 \\
\hline
\end{tabular}

\section{Infrared spectra}

Regarding the assignments of FTIR spectrum of the synthetic free ligand ethyl 2-oxo-2-(4-oxo3-(1-(pyridin-3-yl)ethylideneamino)-2-thioxoimid azolidin-1-yl)acetate (4) (Table 2), there are four characteristic frequencies at $1715 \mathrm{~cm}^{-1}, 1614 \mathrm{~cm}^{-1}, 1602 \mathrm{~cm}^{-1}$, and $835 \mathrm{~cm}^{-1}$, these bands can be assigned to the stretching vibration $(C=O)$ ester group [29], stretching vibration $(C=O)$ 
thioxoimidazolidine ring, stretching frequency of the $(\mathrm{N}-\mathrm{C})$ of $\mathrm{N}-\mathrm{C}=\mathrm{S}$ [30], and the stretching vibration band of $(\mathrm{C}=\mathrm{S})$ of thioxoimidazolidine ring, respectively. The medium-to-weak bands within the range of $3400-33300 \mathrm{~cm}^{-1}$ areattributed to the stretching vibration symmetry and asymmetry $v(\mathrm{O}-\mathrm{H})$ of the coordinated water molecules. A new absorption strong band presence at $2076 \mathrm{~cm}^{-1}$ in the spectra of all complexes is assigned to the stretching vibration band of $(\mathrm{C} \equiv \mathrm{N})$ of the acetonitrile ligand [29]. The band $(\mathrm{C} \equiv \mathrm{N})$ which was characteristic to acetonitrile (L2) was observed in all complexes at $2076 \mathrm{~cm}^{-1}$ this indicated coordination of (L2) with the metal ion through two nitrogen atoms [29]. In comparable between free ligand (L1) and the isolated complexes, it can be notice that the very strong intensity band occurs at $1715 \mathrm{~cm}^{-1}$ due to $\mathrm{vC}=\mathrm{O}$ ester group is absent or shifted to lower wavenumbers, this indicates that the coordination mode towards central metal ion takes place through oxygen of ester group. The stretching vibration band of the $v(\mathrm{~N}-\mathrm{C}=\mathrm{S})$ thioxoimidazolidine ring in all complexes has been shifted to lower frequency at $1562 \mathrm{~cm}^{-1}$. This displacement is also confirmed the involvement of thioxoimidazolidinenitrogen in the coordination. The stretching vibration bands of both $v(\mathrm{C}=\mathrm{O})$ and $v(\mathrm{C}=\mathrm{S})$ of thioxoimidazolidine ring are slightly affected due to the non-involvement of oxygen and sulfur thioxoimidazolidinein the complexation with respected metal ions. New bands were found in the spectrum of the complexes were lie in the range from $\left(571-536 \mathrm{~cm}^{-1}\right)$ and $\left(442-437 \mathrm{~cm}^{-1}\right)$ which are not present in the spectrum of the free ligand were attributed to $v(\mathrm{M}-\mathrm{O})$ and $v(\mathrm{M}-\mathrm{N})$ vibrations, respectively [29].

Table 2. Infrared spectral assignments of $\mathrm{L} 1, \mathrm{Cu}(\mathrm{II}), \mathrm{Co}(\mathrm{II})$, and $\mathrm{Ni}(\mathrm{II})$ complexes.

\begin{tabular}{|l|c|c|c|c|}
\hline \multirow{2}{*}{ Assignments } & \multicolumn{4}{|c|}{ Compounds } \\
\cline { 2 - 5 } & $\mathrm{L} 1$ & $\mathrm{Cu}(\mathrm{II})$ complex & Co(II) complex & Ni(II) complex \\
\hline$v(\mathrm{C} \equiv \mathrm{N})$ acetonitrile & - & 2076 & 2076 & 2076 \\
\hline$v(\mathrm{C}=\mathrm{O})$ ester & 1715 & - & - & - \\
\hline$v(\mathrm{C}=\mathrm{O})$ thioxoimidazolidine & 1614 & 1611 & 1611 & 1609 \\
\hline$v(\mathrm{~N}-\mathrm{C}=\mathrm{S})$ thioxoimidazolidine & 1602 & 1562 & 1562 & 1500 \\
\hline$v(\mathrm{C}=\mathrm{S})$ & 835 & 826 & 826 & 826 \\
\hline$v(\mathrm{M}-\mathrm{O})$ & - & 571 & 571 & 536 \\
\hline$v(\mathrm{M}-\mathrm{N})$ & - & 440 & 442 & 437 \\
\hline
\end{tabular}

\section{Electronic and magnetic measurements}

The electronic absorption spectrum of copper(II) complex shows an absorption band at 14598 $\mathrm{cm}^{-1}$ attributed to ${ }^{2} \mathrm{E}_{\mathrm{g}} \rightarrow{ }^{2} \mathrm{~T}_{2 \mathrm{~g}}$ transition suggesting an octahedral geometry [31]. The magnetic moment of $\mathrm{Cu}$ (II) complex is $1.81 \mathrm{~B} . \mathrm{M}$. corresponds to one unpaired electron, which agrees to an octahedral geometry [32]. The spectrum of the cobalt(II) complex was displayed three characteristic absorption bands at 10989, 14245 and $18975 \mathrm{~cm}^{-1}$, respectively, these bands can be attributed to the ${ }^{4} \mathrm{~T}_{1 \mathrm{~g}}(\mathrm{~F}) \rightarrow{ }^{4} \mathrm{~T}_{2 \mathrm{~g}}(\mathrm{~F}),{ }^{4} \mathrm{~T}_{1 \mathrm{~g}}(\mathrm{~F}) \rightarrow{ }^{4} \mathrm{~A}_{2 \mathrm{~g}}$ and ${ }^{4} \mathrm{~T}_{1 \mathrm{~g}}(\mathrm{~F}) \rightarrow{ }^{4} \mathrm{~T}_{1 \mathrm{~g}}(\mathrm{P})$ electronic transitions, respectively. The magnetic moment value is 4.42 B.M agreed with octahedral geometry [32]. The electronic absorption spectrum of the nickel(II) complex included a three transition bands observed at 16000,18622 and $28735 \mathrm{~cm}^{-1}$ due to the transitions of ${ }^{3} \mathrm{~A}_{2 \mathrm{~g}} \rightarrow{ }^{3} \mathrm{~T}_{2 \mathrm{~g}}(\mathrm{~F}),{ }^{3} \mathrm{~A}_{2 \mathrm{~g}} \rightarrow{ }^{3} \mathrm{~T}_{1 \mathrm{~g}}(\mathrm{P})$ and charge transfer bands respectively. The magnetic moment value is 3.28 B.M in good matched with an octahedral geometry [32]. According to the molecular formulae, an octahedral geometry was proposed for all these complexes (Figure 9).

\section{Thermogravimetric analyses}

The data assignments of TG and DTA curves of $\mathrm{Cu}(\mathrm{II}), \mathrm{Co}(\mathrm{II})$, and $\mathrm{Ni}(\mathrm{II})$ complexes are listed in Table 3. 


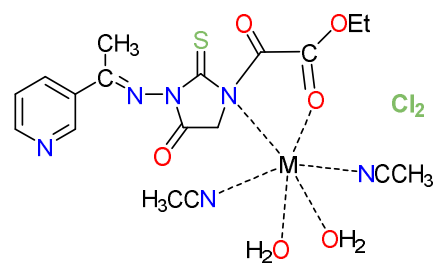

Figure 9. Suggested structures of the synthesized $\mathrm{Cu}(\mathrm{II}), \mathrm{Co}(\mathrm{II})$, and $\mathrm{Ni}(\mathrm{II})$ complexes.

Table 3. Thermal analyses of $\mathrm{Cu}(\mathrm{II}), \mathrm{Co}(\mathrm{II})$, and $\mathrm{Ni}(\mathrm{II})$ complexes.

\begin{tabular}{|c|c|c|c|c|c|c|}
\hline \multirow[b]{2}{*}{ Complexes } & \multirow{2}{*}{$\begin{array}{c}\text { DTA } \\
\text { peak } /{ }^{\circ} \mathrm{C}\end{array}$} & \multirow{2}{*}{$\begin{array}{l}\text { Temp. } \\
\text { range } /{ }^{\circ} \mathrm{C}\end{array}$} & \multicolumn{2}{|c|}{ Weight loss } & \multicolumn{2}{|c|}{ Assignments } \\
\hline & & & Calcd. & Found & Loss species & $\begin{array}{ll}\text { Residual } & \text { species } \\
\text { found/(calcd.) } & \\
\end{array}$ \\
\hline $\mathrm{Cu}(\mathrm{II})$ & 325350 & $25-400$ & 77.09 & 77.66 & $\begin{array}{c}2 \mathrm{H}_{2} \mathrm{O}+ \\
2 \mathrm{CH}_{3} \mathrm{CN} \\
\mathrm{L1}\end{array}$ & $\mathrm{CuCl}_{2}(22.34 /(22.91))$ \\
\hline $\mathrm{Co}(\mathrm{II})$ & $\begin{array}{l}300 \\
350 \\
375\end{array}$ & $25-400$ & 77.70 & 74.83 & $\begin{array}{c}2 \mathrm{H}_{2} \mathrm{O}+ \\
2 \mathrm{CH}_{3} \mathrm{CN} \\
\mathrm{L} 1\end{array}$ & $\mathrm{CoCl}_{2}(25.17 /(22.30))$ \\
\hline $\mathrm{Ni}(\mathrm{II})$ & 350 & $25-400$ & 77.74 & 77.54 & $\begin{array}{c}2 \mathrm{H}_{2} \mathrm{O}+ \\
2 \mathrm{CH}_{3} \mathrm{CN} \\
\mathrm{Ll}\end{array}$ & $\mathrm{NiCl}_{2}(22.46 /(22.26))$ \\
\hline
\end{tabular}

The thermogravimetric complexes $\left[\mathrm{M}(\mathrm{L} 1)\left(\mathrm{CH}_{3} \mathrm{CN}\right)_{2}\left(\mathrm{H}_{2} \mathrm{O}\right)_{2}\right] \mathrm{Cl}_{2}$ where $\mathrm{M}=\mathrm{Co}(\mathrm{II}) \mathrm{Ni}(\mathrm{II})$, and $\mathrm{Cu}$ (II) are stable up to the temperature of $400{ }^{\circ} \mathrm{C}$ and the totally experimental mass losses are $77.66,74.83$, and $77.54 \%$ in good agreement with calculated data $77.09,77.70$, and $77.74 \%$, respectively, which corresponds loss of two coordinated water, two acetonitrile (L2) molecules and L1 ligand moiety. The metal chlorides are a final thermal decomposition product with experimental values as $22.34,25.17$, and $22.46 \%$ matched with calcd. data $22.91,22.30$, and $22.26 \%$.

Table 4. Antibacterial efficient of free ligand and its $\mathrm{Cu}(\mathrm{II}), \mathrm{Co}(\mathrm{II})$, and $\mathrm{Ni}(\mathrm{II})$ complexes.

\begin{tabular}{|c|c|c|c|c|c|c|c|}
\hline \multirow{2}{*}{ Compounds } & \multicolumn{4}{|c|}{ G+ bacteria } & \multicolumn{2}{c|}{ G-bacteria } & \multicolumn{2}{c|}{ Fungi } \\
\cline { 2 - 8 } & $\begin{array}{l}\text { Bacillus } \\
\text { subtillis }\end{array}$ & $\begin{array}{l}\text { Streptococcus } \\
\text { pneumonia }\end{array}$ & $\begin{array}{l}\text { Staphyloccoccus } \\
\text { aurease }\end{array}$ & $\begin{array}{l}\text { E. } \\
\text { coli }\end{array}$ & $\begin{array}{l}\text { Pesudomonas } \\
\text { Sp. }\end{array}$ & $\begin{array}{l}\text { Aspergillus } \\
\text { nigaer }\end{array}$ & $\begin{array}{l}\text { Penicillium } \\
\text { Sp. }\end{array}$ \\
\hline Ligand & ++ & + & + & - & + & - & + \\
\hline $\mathrm{Cu}(\mathrm{II})$ & ++ & +++ & + & - & ++ & + & +++ \\
\hline $\mathrm{Co}(\mathrm{II})$ & ++ & +++ & + & + & +++ & + & +++ \\
\hline $\mathrm{Ni}(\mathrm{II})$ & +++ & ++ & +++ & ++ & ++ & ++ & +++ \\
\hline
\end{tabular}

Biological analyses

The antimicrobial activity of ethyl 2-oxo-2-(4-oxo-3-(1-(pyridin-3-yl)ethylideneamino)-2thioxoimid azolidin-1-yl)acetate (4) free ligand and its $\mathrm{Cu}(\mathrm{II}), \mathrm{Co}(\mathrm{II})$, and $\mathrm{Ni}(\mathrm{II})$ complexes were screened against G+bacteria (Bacillus subtillis, Streptococcus pneumonia, and Staphyloccoccus aurease), G-bacteria (E. coli, and Pesudomonas Sp.) and fungi (Aspergillus nigaer, and Penicillium Sp.) based on the paper disc diffusion method (Table 4). The metal complexes showed an activity rather than free ligand against all organisms. $\mathrm{Cu}(\mathrm{II}), \mathrm{Co}(\mathrm{II}), \mathrm{Ni}(\mathrm{II})$ complexes show moderate activity with Streptococcus pneumonia, E. coli, Pesudomonas Sp., Aspergillus nigaer, and Penicillium Sp. Copper complex do not possess any activity against $E$. coli. The metal complexes are more active than the ligand L1 expectedly due to chelation, which 
reduced the polarity of the metal atom, mainly because of partial sharing of its positive charge with donor groups of the ligand and possible $\pi$-electron delocalization, on the aromatic rings. This increased the lipophilic character, favoring, its permeation into the bacterial membrane, causing the death of the organisms.

\section{CONCLUSION}

The ligand ethyl 2-oxo-2-(4-oxo-3-(1-(pyridin-3-yl)ethylideneamino)-2-thioxoimid azolidin-1yl)acetate (4) was successfully synthesized. The mixed ligands L1 and L2 (acetonitrile) were coordinated to three different transition metal ions $\left(\mathrm{Cu}^{\mathrm{II}}, \mathrm{Co}^{\mathrm{II}}\right.$, and $\left.\mathrm{Ni}^{\mathrm{II}}\right)$ via oxygen and nitrogen atoms to afford the corresponding complexes. All the complexes were six-coordinated and exhibited octahedral geometry. Preliminary in vitro antibacterial and antifungal studies indicated that all the complexes obtained showed a moderate activity against the tested bacterial and fungi strains and a higher activity compared to the ligand, L1.

\section{ACKNOWLEDGEMENT}

Taif University Researches Supporting Project number (TURSP-2020/07), Taif University, Taif, Saudi Arabia.

\section{REFERENCES}

1. Horton, D.A.; Bourne, G.T.; Smyth, M.L. The combinatorial synthesis of bicyclic privileged structures or privileged substructures. Chem Rev. 2003, 103, 893-899.

2. Al-Salama, Z.T. Apalutamide: First global approval. Drugs 2018, 78, 699-705.

3. Johnson, T.B.; Scott, W.M. Hydantoins: The synthesis of 2-thiohydantoins from acyl derivatives of $\alpha$-aminoacids. J. Am. Chem. Soc. 1913, 35, 1208-1213.

4. Dellis, A.E.; Papatsoris, A.G.; Apalutamide: The established and emerging roles in the treatment of advanced prostate cancer. Expert. Opin. Investig. Drugs 2018, 27, 553-559.

5. Chong, J.T; Oh, W.K; Liaw, B.C. Profile of apalutamide in the treatment of metastatic castration-resistant prostate cancer: evidence to date. Onco. Targets Ther. 2018, 11, 21412147.

6. Kyriakopoulos, C.E.; Heath, E.I.; Ferrari, A.; Sperger, J.M.; Singh, A.; Perlman, S.B.; Roth, A.R.; Perk, T.G.; Modelska, K.; Porcari, A.; Duggan, W.; Lang, J.M.; Jeraj, R.; Liu, G. Exploring spatial-temporal changes in 18F-sodium fluoride PET/CT and circulating tumor cells in metastatic castration-resistant prostate cancer treated with enzalutamide. J. Clin. Oncol. 2020, 38, 3662-3671.

7. Seki, M.; Kajiwara, D.; Mizutani, H.; Minamiguchi, K.; Analysis of novel enzalutamideresistant cells: Upregulation of testis-specific Y-encoded protein gene promotes the expression of androgen receptor splicing variant 7. Transl. Cancer Res. 2020, 9, 6232-6245.

8. Qamar, R.; Saeed, A.; Saeed, M.; Shah, B.H.; Ashraf, Z.; Abbas, Q.; Yum Seo, S.Y. Synthesis and enzyme inhibitory kinetics of some novel 3-(substituted benzoyl)-2thioxoimidazolidin-4-one derivatives as $\alpha$-glucosidase $/ \alpha$-amylase inhibitors. Med. Chem. Res. 2018, 27, 1528-1537.

9. Takahashi, A.; Matsuoka, H.; Ozawa, Y.; Uda, Y. Antimutagenic properties of 3,5disubstituted 2-thiohydantoins. J. Agric. Food Chem. 1998, 46, 5037-5041.

10. El-Barbary, A.A.; Khodair, A.I.; Pedersen, E.B.; Nielsen, C. S-Glucosylatedhydantoins as new antiviral agents. J. Med. Chem. 1994, 37, 73-77.

11. (a) Chérouvrier, J.R.; Carreaux, F.; Bazureau, J.P. Reactivity of 2-thiohydantoins towards various electrophilic reagents: Applications to the synthesis of new 2-ylidene-3,5-dihydro-4Himidazol-4-ones. Molecules 2004, 9, 867-875. (b) Khodair, A.I.; El-Subbagh, H.I.; ElEmam, A.A. Synthesis of certain 5-substituted 2-thiohydantoin derivatives. Bull. Chim. Farm. 1997, 136, 561-567.

12. Froelich, E.; Fruehan, A.; Jackman, M.; Kirchner, F.K.; Alexander, E.J.; Archer, S. 5Heptyl-2-thiohydantion, a new antitubercular agent. J. Am. Chem. Soc. 1954, 76, 3099-4105. 
13. Al-Obaid, A.M.; El-Subbagh, H.I.; Khodair, A.I.; Elmazar, M.M. 5-Substituted-2thiohydantoin analogs as a novel classantitumor agent. Anticancer Drugs 1996, 7, 873-878.

14. Curran, A.C.W. Thiohydantoin derivatives. U. S. Pat. 3,984,430, 1976.

15. Tompkins, J.E. 5,5-Diaryl-2-thiohydantoins and 5,5-diaryl $\mathrm{N}^{3}$-substituted 2-thiohydantoins as potential hypolipidemic agents. J. Med. Chem. 1986, 29, 855-864.

16. Marx, J.V.; Richert, D.A.; Westerfeld, W.W. Peripheral inhibition of thyroxine by thiohydantoins derived from aminoacids. J. Med. Chem. 1970, 13, 1179-1181.

17. Lacroix, G.; Bascou, J.P.; Perez, J.; Gadras, A. Fungicidal optically active 1-(mono-or substituted amino)-2-substituted-4,4-disubstituted-2-imidazolin-5-ones and 5-thiones corresponding. U. S. Pat. 6,018,052, 2000.

18. Mo, B.; Li, J.; Liang, S. A method for preparation of amino acid thiohydantoins from free amino acids activated by acetyl chloride for development of protein c-terminal sequencing. Anal. Biochem. 1997, 249, 207-211.

19. Sahyon, H.A.; El-Bindary, A.A.; Shoair, A.F.; Abdellatif, A.A. Synthesis and characterization of ruthenium(III) complex containing 2-aminomethyl benzimidazole, and its anticancer activity of in vitro and in vivo models. J. Mol. Liq. 2018, 255, 122-134.

20. Shoair, A.F.; El-Bindary, A.A.; El-Ghamaz, N.A.; Rezk, G.N. Synthesis, characterization, DNA binding and antitumor activities of $\mathrm{Cu}(\mathrm{II})$ complexes. J. Mol. Liq. 2018, 269, 619-638.

21. El-Gammal, O.A.; Mohamed, F. Sh.; Resk, G.N.; El-Bindary, A.A. Synthesis, characterization, catalytic, DNA binding and antibacterial activities of $\mathrm{Co}(\mathrm{II}), \mathrm{Ni}(\mathrm{II})$ and $\mathrm{Cu}(\mathrm{II})$ complexes with new Schiff base ligand. J. Mol. Liq. 2021, 326, 115223.

22. Kiwaan, H.A.; El-Mowafy, A.S.; El-Bindary, A.A. Synthesis, spectral characterization, DNA binding, catalytic and in vitro cytotoxicity of some metal complexes. J. Mol. Liq. 2021, 326115381

23. Bauer, A.W.; Kirby, W.M., Sherris, C.; Turck, M. Antibiotic susceptibility testing by a standardized single disk method. Amer. J. Clinical Pathology. 1966, 45, 493-496.

24. Pfaller, M.A.; Burmeister, L.; Bartlett, M.A.; Rinaldi, M.G. Multicenter evaluation of four methods of yeast inoculum preparation. J. Clin. Microbiol. 1988, 26, 1437-1441.

25. National Committee for Clinical Laboratory Standards, Performance Vol. antimicrobial susceptibility of Flavobacteria, 1997.

26. National Committee for Clinical Laboratory Standards. 1993. Methods for dilution antimicrobial susceptibility tests for bacteria that grow aerobically. Approved standard M7A3. National Committee for Clinical Laboratory Standards, Villanova, Pa.

27. Refat, M.S. Synthesis and characterization of norfloxacin-transition metal complexes (group 11, IB): Spectroscopic, thermal, kinetic measurements and biological activity. Spectrochimica Acta A 2007, 68, 1393-1405.

28. Refat, M.S. Complexes of uranyl(II), vanadyl(II) and zirconyl(II) with orotic acid "vitamin B13": Synthesis, spectroscopic, thermal studies and antibacterial activity. J. Mol. Struct. 2007, 842, 24-37.

29. Nakamoto, K, Infra Red Spectra of Inorganic and Coordinated Compounds, John Wiley: New York; 1963; p 167.

30. Randall, H.M.; Fowler, R.G.; Fuson, N.; Dangl, J.R. Infrared Determination of Organic Structures. D. Van Nostrand: New York; 1949.

31. Lever, A.B.P., Mantovani, E. Far-infrared and electronic spectra of some bis(ethylenediamine) and related complexes of copper(II) and the relevance of these data to tetragonal distortion and bond strengths. Inorg. Chem. 1971, 10, 817-826.

32. Lever, A.B.P. Inorganic Electronic Spectroscopy, Elsevier: Amsterdam; 1968.

33. Mishra, A.P.; Jain, R.K. Microwave synthesis, spectroscopic, thermal and biological significance of some transition metal complexes containing heterocyclic ligands. Chem. Pharm. Res. 2010, 2, 51-61. 